\title{
MATERIAL CULTURE AND ANTIHUMAN SUBJECTIVTIES IN POSTMODERNIST LITERATURE
}

\author{
BELÉN PiQueRAS \\ Autonomous University of Madrid \\ belen.piqueras@uam.es
}

\begin{abstract}
The relation between subject and object in contemporary societies is a key concern of much postmodernist literature, authors often denouncing the superfluous pervasiveness of material culture in our lives and our absurd dependence on the artificial systems of meaning that we project on the world of things.

The antihumanism that is commonly identified with postmodern culture finds a congenial formulation in Postructuralist theories, which consider meaning not as an absolute concept, but always arising of a web of signs that interrelate; the key issue is that for most Postructuralist thinkers -among them Jean Baudrillard and his definition of the 'hyperreal'- these codes on which culture is founded always precede the individual subject, annihilating all prospects of human agency.

Postmodern authors like Thomas Pynchon, Don Delillo or William Gibson foster the debate on the nature of those underlying structures, and offer manifold portraits of these frail, commodified, and antihuman subjectivities that are very often the product of progress.
\end{abstract}

Keywords: Material culture, postmodernism, poststructuralism, Baudrillard, simulacra, antihumanism. 


\title{
CULTURA MATERIAL Y SUBJETIVDADES ANTIHUMANAS EN LA LITERATURA POSTMODERNISTA
}

\begin{abstract}
RESUMEN. La relación entre el sujeto y el objeto en las sociedades contemporáneas es uno de los intereses principales de gran parte de la literatura postmoderna, y sus autores denuncian a menudo la invasión superflua que la cultura de lo material ejerce en nuestras vidas, así como nuestra absurda dependencia de las estructuras semánticas artificiales que proyectamos sobre el mundo de los objetos.

El antihumanismo que comúnmente se identifica con la cultura postmoderna encuentra una idónea formulación en las teorías post-estructuralistas, que entienden el significado no como un concepto absoluto, sino originado en un entramado de signos que se relacionan entre sí; el tema clave es que para la mayoría de los pensadores post-estructuralistas -entre ellos Jean Baudrillard y su definición del 'hiperreal'- estas estructuras en las que se fundamenta la cultura siempre preceden al individuo, y aniquilan cualquier posibilidad de determinación humana.
\end{abstract}

Autores postmodernos como Thomas Pynchon, Don Delillo o William Gibson alimentan el debate acerca de la naturaleza de esas estructuras subyacentes, y ofrecen múltiples retratos de las subjetividades frágiles, consumibles y antihumanas que a menudo son el fruto del progreso.

Palabras clave: Cultura material, postmodernismo, post-estructuralismo, Baudrillard, simulacra, antihumanismo.

Received 14 June 2015

Revised version accepted 11 April 2016

The relation between subject and object in contemporary societies is a key concern of much postmodernist literature, authors often denouncing the superfluous pervasiveness of material culture in our lives and our absurd dependence on the artificial systems of meaning that we project on the world of things. As one of the most important theoreticians of the postmodern, Jean Baudrillard, said in "The Precession of Simulacra" - originally "La precession des simulacres" in Simulacra et Simulation, 1981- we live in a world where the signs of the real have substituted the real, a world of recurrent simulation where the real has mutated into the 'hyperreal'.

It is the whole traditional world of causality that is in question: the perspectival, determinist mode, the "active," critical mode, the analytic mode -the distinction 
between cause and effect, between active and passive, between subject and object, between the ends and the means (Baudrillard 2010: 30).

According to Baudrillard, in our era:

[t]he real is produced from miniaturized cells, matrices, and memory banks, models of control -and it can be reproduced an indefinite number of times from these. It no longer needs to be rational, because it no longer measures itself against either an ideal or negative instance. It is no longer anything but operational. In fact, it is no longer really the real, because no imaginary envelops it anymore. It is a hyperreal, produced from a radiating synthesis of combinatory models in a hyperspace without atmosphere (2).

Science and technology are directly responsible for this "desert of the real", as Baudrillard describes it, where the subject is 'dehumanized', essentially defined by its projection in a material world of objects, images and data. And that is because we place our science in service of restoring a visible order, an order which no longer masters anything but which strives to immortalize a hidden dimension of the real, whether past or present, exterminating it. It is the "Irreparable violence toward all secrets, the violence of a civilization without secrets" says Baudrillard (11), as he concludes ironically:

Everywhere we live in a universe strangely similar to the original -things are doubled by their own scenario. But this doubling does not signify, as it did traditionally, the imminence of their death- they are already purged of their death, and better than when they are alive; more cheerful, more authentic, in the light of their model, like the faces in funeral homes." (11)

Postmodern authors like Thomas Pynchon, Don Delillo, or William Gibson explore in their novels the ambiguous and conflicting relation between the subject and the object in postindustrial societies; for these authors, material culture provides the subject with the consolation of meaning and control in an otherwise undecipherable and most often insufferable reality, but they also consider and denounce that these cultural forms are falsely reassuring for the subject, who paradoxically falls often into solipsistic dissolution.

From a literary point of view, and with examples taken from these authors' texts, this article will show how in postmodern societies the object -most often a technological one- reigns supreme, getting to determine the very constitution of the social subject; it will also try to illustrate how science and technology are essential in the reformulation of the relationship between contemporary 
individuals and their milieu, as well as in the reconceptualization of the very notion of subject'.

The antihumanism ${ }^{2}$ that is commonly associated with postmodern culture finds a congenial formulation in Postructuralist theories, which consider meaning not as an absolute concept, but always arising of a web of signs that interrelate; everything makes sense within a code where parts get connected by contrast, and not by their relation to an external reality. The key issue is that for most Postructuralist thinkers, these codes on which culture is founded always precede and condition the individual subject, annihilating all prospects of human agency.

In this line, Jean Baudrillard develops the idea that objects have value as signs, and it is this value that modern societies stress and encourage, meaning becoming a commodity that very often drives subjects to the absurdity of consumption in their quest for social recognition and status. This is what Don DeLillo seems to be denouncing with the list that opens White Noise and that depicts the amival of students to the College-on-the-Hill for the new course:

The station wagons arrived at noon, a long shining line that coursed through the west campus. In single file they eased around the orange I-beam sculpture and moved toward the dormitories. The roofs of the station wagons were loaded down with carefully secured suitcases full of light and heavy clothing; with boxes of blankets, boots and shoes, stationery and books, sheets, pillows, quilts; with rolled-up rugs and sleeping bags; with bicycles, skis, rucksacks, English and Western saddles, inflated rafts. As cars slowed to a crawl and stopped, students sprang out and raced to the rear doors to begin removing the objects inside; the stereo sets, radios, personal computers; small refrigerators and table ranges; the cartons of phonograph records and cassettes; the hairdryers and styling irons; the tennis rackets, soccer balls, hockey and lacrosse sticks, bows and arrows; the controlled substances, the birth control pills and devices; the junk food still in shopping bags -onion-and garlic chips, nacho

\footnotetext{
1 The works analyzed here have been chosen to illustrate a solid trend in recent narrative that deals with the different dangers to which our postmodern culture of mediation and simulation exposes individuals and communities. They have paved the way for more recent works like David Foster Wallace's Infinite Jest (1996), Mark Danielewski's House of Leaves (2000) or Steve Tomasula's The Book of Portraiture (2006), among many others.

2 This concept comes from social theory and philosophy, and it denies the centrality that human nature and human agency have traditionally had in the history of western thought. Antihumanism yields to the consequences of the "death of Man," as introduced by some post-structuralist theorists, above all Michel Foucault (see The Order of Things: An Archaeology of the Human Sciences, 1971). It is applied here to refer to a postmodern self that for different reasons -commonly associated with the epistemological intricacy of material culture- experiences a disordered intellectual activity and a consensual disembodiment where the human discreteness finally dissolves.
} 
thins, peanut crème patties, Waffelos and Kabooms, fruit chews and toffee popcorn; the Dum-Dum pops, the Mystic mints. (DeLillo 1985: 3)

This lyrically heterogeneous list that represents American middle-class consumerism and habits must be interpreted as a rhetorical performance of the superfluous materialism that affects modern societies. From a Poststructuralist conception, the subject is always inscribed in 'language', as in like manner characters in White Noise get defined by what they possess and consume, literally supplanted as subjects by a set of objects with which they try to control the image projected, transforming their own reality in a mode of social exchange, as illustrated in the following quotation:

The students greet each other with comic cries and gestures of sodden collapse. Their summer has been bloated with criminal pleasures, as always. The parents stand sun-dazed near their automobiles, seeing images of themselves in every direction. The conscientious suntans. The well-made faces and wry looks. They feel a sense of renewal, of communal recognition. The women crisp and alert, in diet trim, knowing people's names. Their husbands content to measure out the time, distant but ungrudging, accomplished in parenthood, something about them suggesting massive insurance coverage. This assembly of station wagons, as much as anything they might do in the course of the year, more than formal liturgies or laws, tells the parents they are a collection of the like-minded and the spiritually akin, a people, a nation. (1985: 4)

In this communal act of simulation, the original subject vanishes behind the appearances of the conceptual subject, or as Baudrillard would put it, it is the map that precedes the territory -it is "The Precession of Simulacra". "Something has disappeared -says Baudrillard- the sovereign difference between one and the other" (2). For Baudrillard the charm of abstraction vanishes when there is not a clear distinction between the real and its representation, -or as Walter Bejamin says in "The work of art in the age of Mechanical Reproduction" -originally published in German in Zeitschrift für Sozialforschung in 1936, and first collected in English in 1968 as Illuminations- it is the "aura" of originality that disappears in contemporary societies ${ }^{3}$. The subject also becomes object of reproduction, as it is

\footnotetext{
3 Walter Benjamin speaks in his essay about the contemporary decay of the "aura" by saying: "It rests on two circumstances, both of which are related to the increasing significance of the masses in contemporary life. Namely, the desire of contemporary masses to bring things 'closer' spatially and humanly, which is just as ardent as their bent toward overcoming the uniqueness of every reality by accepting its reproduction. Every day the urge grows stronger to get hold of an object at very close range by way of its likeness, its reproduction. Unmistakably, reproduction as offered by picture magazines and newsreels differs from the image seen by the unarmed eye. Uniqueness and
} 
very often engulfed by the innumerable objects that represent it, getting thus subject and object to coexist at the same level. The subject becomes a formula, an equation of material terms that constitutes a semantic alternative to the uniqueness and human distinctiveness of the self.

It is very illustrative to incorporate here Thomas Pynchon's concept of Entropy. He introduced it in his short story "Entropy" -first published in the Kenyon Review in 1960 and later collected in Slow Learner: Early Stories in 1984where Callisto defines it as "the measure of disorganization for a closed system", and he considers it is valuable because it is "an adequate metaphor to apply to certain phenomena in his own world" such as the consumerist trend away from difference and toward sameness:

He saw, for example, the younger generation responding to Madison Avenue with the same spleen his own had once reserved for Wall Street, and in American 'consumerism' discovered a similar tendency from the least to the most probable, from differentiation to sameness, from ordered individuality to a kind of chaos. He ... envisioned a heat-death for his culture in which ideas, like heat-energy, would no longer be transferred, since each point in it would ultimately have the same quantity of energy, and intellectual motion would, accordingly, cease. (1984: 88)

The apocalyptical nuances of Pynchon's concept of Entropy find an echo in Baudrillard's theories: if for Pynchon the era of entropy entails the annihilation of intellectual activity, for Baudrillard the era of simulation is inaugurated by a liquidation of all referentials (2), including the Subject itself.

One can find innumerable examples in postmodern fiction of how meaning is considered to be always deferred underneath the surfaces of modern life; the postmodern subject is defenceless and overwhelmed by the 'white noise' produced by consumerism, technology and the media, and material culture conveys a high degree of semantic "toxicity" that alienates the individual from his reality and dissolves his potential agency. As Murray Jay Siskind, Jack Gladney's colleague at the university and pop culture theorist in Don Delillo's White Noise, expresses it: "Everything is concealed in symbolism, hidden by veils of mystery and layers of cultural material [...] It's just a question of deciphering, rearranging, peeling off the layers of unspeakability" (DeLillo 1985: 37-8).

permanence are as closely linked in the latter as are transitoriness and reproducibility in the former. To pry an object from its shell, to destroy its aura, is the mark of a perception whose 'sense of the universal equality of things' has increased to such a degree that it extracts it even from a unique object by means of reproduction." (Benjamin 1968: 223). 
For many of DeLillo's characters, reality has become completely mediated and artificial, and technology and the media are direct contributors to that metaphorical 'white noise'. No better example of this than the often quoted passage of "the most photographed barn in America", at the end of the third chapter in White Noise; Murray interprets the essence of the attraction saying: "No one sees the barn' [...] 'Once you've seen the signs about the barn, it becomes impossible to see the barn' [...] They are taking pictures of taking pictures' " (DeLillo 1985: 12-3). Murray understands that reality is shielded, constantly deferred in favour of an artificial double, an equivalent in a system intended, paradoxically, to interpret it and to make it more accessible for man.

There is a sense of remoteness and transcendence that can be perceived in anything mediated by technology in White Noise, and this is interpreted by Frank Lentricchia as a process of mystification that he attributes to "[...] the increasingly nonreferential character of postmodern culture. Since the technological media television, the tabloids, radio, cinema- ultimately create their own reality, they appear to be free from all natural constraints on their constructions. They possess the seemingly limitless power to transform and reconstitute the very being of the contemporary individual" (Lentricchia 1991: 72).

If the epistemological configuration of the modern world depends then on the incessant recumence of signs and models and in the simulated generation of differences, this provokes a feeling that there's some hidden meaning under the inextricable surface of existence, some mysterious connection that eludes man's understanding. This is associated to the notion of paranoia, a central concept that defines the configuration of subjectivity in many postmodernist novels. This is the case of Matt, in Don DeLillo's Underworld:

He was locked to his chair, mind-locked and gravity-trapped, aware of the nature of the state he was in but unable to think himself out. He was bent to the weight of the room, distrustful of everyone and everything here. Paranoid. Now he knew what it meant, this word that was bandied and bruited so easily, and he sensed the connections being made around him, all the objects and shaped silhouettes and levels of knowledge-not knowledge exactly but insidious intent. But not that either-some deeper meaning that existed solely to keep him from knowing what it was. (DeLillo 1997: 421)

The origin of the term paranoia is to be found in psychology, where it is considered a disorder based on systematic delusions: "In contemporary psychiatric practice, the term paranoia is generally reserved for all rare, extreme cases of chronic, fixed, and highly systematized delusions. [...] One of the most common delusions in paranoid disorders is that of persecution" (The New 
Encyclopedia Britannica: Micropaedia. Vol. 9. 1992. 146). But paranoia often takes the shape of a cultural phenomenon that has been studied by such theorists as Fredric Jameson and Ihab Hassan. Paranoia is associated with the idea that everything is connected, and it is grounded on a sustained epistemological uncertainty and suspicion of all the underlying structures that determine our social existence. Paranoia blurs the distinction between the real and the imagined, between the logical and the pathological; under paranoia thought becomes rather than a lens to knowledge, a deterrent of human agency, and a mirror to the subject's frailty.

Paranoia is a central motif that triggers and maintains the action in many postmodernist texts, such as Thomas Pynchon's The Crying of Lot 49, first published in 1967. Oedipa Maas, the questing protagonist in this novel, has unexpectedly been chosen executrix of the will of her now-deceased exboyfriend, Pierce Inverarity, who leaves behind a vast, mysterious estate for Oedipa to sort out. In the process of taking up her mission, Oedipa is both confused and stimulated by the discovery of a sign, the muted post horn. She desperately tries to trace back this arbitrary sign, to see what it stands for. The discovery revolves around a secret organization called Trystero, and an underground alternative mail delivery system. Under a paranoid frenzy Oedipa builds up the story of the Trystero by interpreting random data and facts; however, the multiplying and omnipresent sign of the post horn slips away from her, clues pointing to other clues, leaving the mystery of what appears to be a vast conspiracy without resolution. The reality of the Trystero is in fact a Hyperreality -to use Baudrillard's notion again- a network of connections without clear links to the fictional world projected by the novel.

In Mexico City Oedipa sees the triptych painted by Remedios Varo "Bordando el Manto Terrestre" and she is impressed by the image of the frail girls that are prisoners in the top room of a circular tower, and who are "embroidering a kind of tapestry which spills out the slit windows and into a void seeking hopelessly to fill the void: for all the other buildings and creatures, all the waves, ships and forests of the earth were contained in this tapestry, and the tapestry was the world" (Pynchon 1996: 13). Later on in the novel, and overwhelmed by the enormous amount of 'revelations' she can't decodify, Oedipa recalls the image of the girls in the painting by Varo and writes down on her notebook "shall I project a world?' (Pynchon 1996: 56); her solipsism reveals the vulnerability of the subject when confronting the epistemological void left by the simulacrum of material culture, and the ultimate consequence is the stumbling of intellectual activity and the obliteration of the mind as the vehicle of the human condition. 
But material culture is less and less 'material' each day, since the solidity of many of our daily experiences and of the products we consume is to a great extent illusory. Science precedes man, technology has blended with human existence, and cyberspace has become the ultimate expression of the Hyperreal. It was William Gibson who coined the term 'cyberspace' in 1982 (in "Burning Chrome"), and this is the way it is defined in his novel Neuromancer (first published in 1984):

Cyberspace. A consensual hallucination experienced daily by billions of legitimate operators, in every nation, by children being taught mathematical concepts... A graphical representation of data abstracted from the banks of every computer in the human system. Unthinkable complexity. Lines of light ranged in the non-space of the mind, clusters and constellations of data. Like city lights, receding... (Gibson 1995: 67).

This definition suggests that our illusions and wishes form the basis of a social consensus that dissolves individual human agency; science, the media and the information industry construct attractive images that always lead the subject's choices, and that create an illusory sense of communion. In these modern technological communities, subjects are characterless, iconic reverberations within artificial semantic structures virtually projected on the world of things.

Much of the science fiction we read is set in the distant future, peopled with aliens, and developed in a galactic context; William Gibson's science fiction, however, explores a near-future world that is not so different from ours -in fact Virtual Light, published in 1993, takes place in 2005- and his novels reflect extensively on the transformation of culture by technology.

For Baudrillard, it is almost impossible to write science fiction in the era of the cybernetic and the hyperreal, since there is no real on which to base the imaginary model, the real having been absorbed by the model in a world controlled by the principle of simulation: "in fact, science fiction in this sense is no longer anywhere, and it is everywhere, in the circulation of models, here and now, in the very principle of the surrounding simulation. It can emerge in its crude state, from the inertia itself of the operational world" (126).

In Neuromancer new forms of identity are explored, but they are not so much intended to illustrate how our societies will be in the future as how they are in the present. The novel is a dissection of contemporary Western society, as it illustrates how technology and global capitalism influence our human condition by inducing a world of images and data that have definitely cut loose from any original referent. It is the enactment of the Hyperreal as a form of living. 
Case is the main character in Neuromancer, and he is living the decline of his successful career as brilliant hacker, his nervous system having been damaged with a mycotoxin by his previous bosses, from whom Case made the mistake of stealing. Unable now to use his brain-computer interface to access the global computer network, Case remembers with nostalgia and often dreams of the years he had lived for the "bodiless exultation of cyberspace" when "He'd operated on an almost permanent adrenaline high, a byproduct of youth and proficiency, jacked into a custom cyberspace deck that projected his disembodied consciousness into the consensual hallucination that was the matrix" (Gibson 1995: 11-12).

Many characters in Gibson's novels feel a deep contempt for the flesh, considering the subject's corporeal existence a prison to the infinite possibilities of the mind when projected in cyberspace. Subject and computer are exchangeable concepts in this world, and material culture is now only the intermediate stage to the intangible dimension where one supposedly finds epistemological and ontological completion. Being whole involves self- recognition in the digital imperative of the world, as Eric Packer says in Don DeLillo's Cosmopolis, novel that was turned into a film by David Cronenberg in 2012:

In fact data itself was soulful and glowing, a dynamic aspect of the life process. This was the eloquence of alphabets and numeric systems, now fully realized in electronic form, in the zero-oneness of the world, the digital imperative that defined every breath of the planet's living billions. Here was the heave of the biosphere. Our bodies and oceans were here, knowable and whole. (DeLillo 2003: 24).

In much postmodern fiction the body becomes a commodity, something from which we are not too far nowadays. We live in a world where implants, prostheses and cloning have become almost routine practices, our lives develop around our computer and through it we project our virtual selves on the net. In our technologically mediated existence, the human inside can be supplanted by an artificial outside. For Giles Deleuze and Felix Guattari:

There is no such thing as either man or nature now, only a process that produces the one within the other and couples the machines together. Producing-machines, desiring-machines everywhere... the self and the non-self, outside and inside, no longer have any meaning whatsoever (Deleuze and Guattari 1984: 2).

The sustained representation of an intellectually maimed self that is identified with the antihumanistic vein of most Postmodernist literature can be illustrated 
with references to many works. As an extension of the above mentioned, Pynchon explores in The Crying of Lot 49, in V. (1963), and particularly in Gravity's Rainbow (1973), the fragility of the rational mind and the ephemeral boundaries that separate the animate from the inanimate; in Paul Auster's New York Trilogy stories (1987), characters lose their contours; incapable of interpreting their reality, they 'blend' with it, objectifying themselves in an irreversible process; Gibson's speculations about the viability of marriages between humans and synthetic constructs suggests that their coupling is inevitable because neither of them is ever whole or self-sufficient. In cyberculture the body is redefined as 'fluid' in the sense of lacking clear boundaries, and the instability of matter and mind is foregrounded; adding to this Marshall McLuhan's theories ${ }^{4}$ explaining that technology changes our perceptual habits and that the computer works as an extension of the human mind, it is more than evident that the old notion of the humanistic subject as irreplaceable unity of mind and body is but a dim memory.

Postmodern authors like Thomas Pynchon, Don DeLillo, or William Gibson, project in their novels worlds where an overwhelming material culture disintegrates the mind as the vehicle of individual cognition and agency, and engenders subjectivities that can be defined as antihuman in their blind communion with the images projected by the information industry. This essay has tried to explore how the relation between the subject and the object in postindustrial societies is assessed in postmodern narrative as a conflicting one, as it reveals how many cultural forms are falsely reassuring and ultimately alienating for the social self. Technology and the media have unfolded new conceptual spaces, and many postmodern authors have accepted the challenge, exploring the complex ways in which progress has destabilized conventional forms of knowledge, culture and society.

\section{REFERENCES}

Auster, P. 1987. The New York Trilogy. London: Faber and Faber.

Baudrillard, J. 2010 (1981). Simulacra and Simulation (trans. Sheila Faria Glaser). Ann Arbor: University of Michigan Press.

\footnotetext{
4 The Canadian cultural theorist Marshall McLuhan is a precursor of Baudrillard's postulates concerning the limited scope of human action in post-industrial societies, and he explains how the technological dominant of our culture determines the very ontology of the modern subject. As he stated in Understanding Media (1999) "In this electronic age we see ourselves being translated more and more into the form of information, moving toward the technological extension of consciousness." (McLuhan 1999: 57).
} 
Benjamin, W. 1968. Illuminations (trans. by Harry Zohn). New York: Harcourt, Brace \& World.

Danielewski, M. 2000. House of Leaves. Berkeley (CA): Ten Speed Press.

Deleuze, G. and F. Guattari. 1984 (1972). Anti-Oedipus: Capitalism and Schizophrenia (trans. R. Hurley, M. Seem and H.R. Lane). London: Athlone.

DeLillo, D. 1985. White Noise. New York: Penguin Books.

DeLillo, D. 1997. Underworld. New York: Scribner.

DeLillo, D. 2003. Cosmopolis. London: Picador.

Foster Wallace, D. 2006 (1996). Infinite Jest. New York: Back Bay Books.

Foucault, M. 1971. The Order of Things: An Archaeology of the Human Sciences (trans. Alan Sheridan). New York: Pantheon Books.

Gibson, W. 1986 (1982). Burning Chrome. New York: Ace.

Gibson, W. 1993. Virtual Light. London: Penguin.

Gibson, W. 1995. Neuromancer. London: Harper Collins.

Lentricchia, F, ed. 1991. New Essays on White Noise. Cambridge and New York: Cambridge University Press.

Pynchon, T. 1975. V . London: Pan Books.

Pynchon, T. 1984. Slow Learner. Boston, New York and London: Little, Brown and Company.

Pynchon, T. 1987. Gravity's Rainbow. New York: Penguin Books.

Pynchon, T. 1996. The Crying of Lot 49. London: Vintage, Random House.

The New Encyclopedia Britannica. 1992 (15 ${ }^{\text {th }}$ Edition). Chicago: Encyclopedia Britannica.

Tomasula, S. 2006. The Book of Portraiture. Salt Lake City (Utah): Fiction Collective Two. 